\title{
Salt tolerance mechanisms in Salt Tolerant Grasses (STGs) and their prospects in cereal crop improvement
}

\author{
Swarnendu Roy and Usha Chakraborty ${ }^{*}$
}

\begin{abstract}
Increasing soil salinity in the agricultural fields all over the world is a matter of concern. Salinity poses a serious threat to the normal growth and development of crop plants. What adds to the concern is that all the cereal crops are sensitive to increasing soil salinity. So it is implacable to either search for salinity resistant varieties of crop plants or transform them genetically to sustain growth and reproducibility at increasing salinity stress. For the second perspective, mining the salt tolerant genes in the close relatives of cereal crops apparently becomes important, and most specifically in the salt tolerant grasses (STGS). STGs include the halophytes, facultative halophytes and salt-tolerant glycophytes of the family Poaceae. In this review the potentiality of STGs has been evaluated for increasing the salinity tolerance of cereal crops. STGs are capable of surviving at increasing salt stress by utilizing different mechanisms that include vacuolization of toxic $\mathrm{Na}^{+}$and $\mathrm{Cl}^{-}$in mature or senescing leaves, secretion of excess salts by salt glands, accumulation of osmolytes like proline and glycine betaine, and scavenging of ROS by antioxidative enzymes. The STGs are a therefore a potent source of salt tolerant genes.
\end{abstract}

Keyword: Salt tolerant grasses (STGs); Osmoprotectants; Reactive oxygen species (ROS); Model STGs; Transgenic plants

\section{Review}

\section{Introduction}

Salinity is one of the major abiotic stresses that hinder the performance of the crop plants all over the world. In most crop plants, the main toxic component of salinity is $\mathrm{Na}^{+}$and $\mathrm{Cl}^{-}$, which interferes with the normal physiological processes, such as enzyme activities and protein synthesis, as well as causing osmotic imbalances (Munns and Tester 2008). Due to these toxic effects, crops grown on saline soils have significantly reduced yield (Lauchli and Grattan 2007). According to UNEP Report, globally some $20 \%$ of agricultural land under irrigation has become salt affected (Nellemann et al. 2009). It is known that 40\% of the increase in food production over the last 50 years came from irrigated land (Prakash and Stigler 2012). Also the world population is estimated to double in the next 50 years, so greater yield is required to feed the growing population (Chaves and Davies 2010). The agricultural scenario is thus getting worse as the agricultural land is

\footnotetext{
* Correspondence: ucnbu2012@gmail.com

Plant Biochemistry Laboratory, Department of Botany, University of North Bengal, Siliguri, 734013 West Bengal, India
}

limited and salt-resistant varieties of crop plants are not available, so there is an emergent need to make the crop plants suitable to this changing scenario.

In this situation, one of the ways is to make the crop plants genetically engineered to sustain their growth and productivity in such challenging environment. For this purpose, it is important to look among the wild relatives of crop plants that carry a good gene pool (Sengupta and Majumder 2009). According to Tester and Bacic (2005), tracing the abiotic stress related genes in the grasses, which are close relatives of cereal crops could lead to the better understanding of the mechanism of salinity tolerance and even introgressing their genes in the cereal genome for inducting better tolerance to salinity. The salt sensitivity of all the grasses is not similar to the cereals and some of these grasses have inherent ability to withstand varying degrees of salt concentrations. According to Flowers et al. (2010), the order Poales accounts for approximately $8.1 \%$ of the total halophytic species. (Flowers and Colmer 2008) has defined a halophytic species as one that can survive to complete their life cycle in at least $200 \mathrm{mM}$ salt solution. In the last decade 
the attempt for mining more and more salt tolerant genes from the grasses has increased gradually, also the genes have been characterized and transformed in different model plants to test their efficacy in enhancing salinity tolerance.

In this review, term 'Salt Tolerant Grasses (STGs)' has been used for all the grass species including the halophytes, facultative halophytes and salt-tolerant glycophytes. These STGs are a potent source of salt tolerant genes, supported by the occurrence of several traits that works constitutively for imparting salinity tolerance. Thus the STGs offer an ideal system for comparative studies with other cereal crops for mining out more and more novel genes for salt tolerance. Also the non STGs including the cereal crops are also the source of salt tolerant genes, but the prime focus of this review will be on the STGs to understand their salt tolerance mechanism and assess their potentiality as a source of genes for improving the salt tolerance of cereal crops.

\section{STGs: an overview}

The grass family (Poaceae) comprises approximately 10000 species classified in to 600-700 genera (Watson and Dallwitz 1992). According to Gorham et al. (1985) two different mechanisms of salt tolerance are present in plant species growing at high salinities. In succulent Chenopodiaceae, osmotic balance is maintained by the accumulation of $\mathrm{Na}^{+}$and $\mathrm{Cl}^{-}$in shoots followed by synthesis of osmolytes like glycine betaine. In halophytic grasses on the other hand, salt tolerance is mainly achieved either by limiting the influx of salts into the shoots, which results in reduced growth rates under saline conditions or by excluding the excess salt by salt glands. Liphschitz and Waisel (1974) reported 25 species of grasses where salt glands were observed of which mostly were glycophytic, and their distribution was confined to non-saline habitats. Most of the grasses like Distichlis, Aeluropus of the tribe Aeluropodeae are typically halophytes (Liphschitz and Waisel 1974; Barhoumi et al. 2008; Oross and Thomson 1982). Halophytic grasses are highly salt tolerant due to their ability to exclude salt from the internal tissues. Tolerance to salinity in the halophytic grasses like Puccinellia and Thinopyrum is facilitated by the development of adventitious roots and a superior ability to maintain negative membrane potential in root cells, resulting in greater retention of $\mathrm{K}^{+}$in shoots (Teakle et al. 2013). Also in most of the glycophytic grasses like Cynodon, Sporobolus, Zoysia and Buchloe salinity tolerance was positively correlated with $\mathrm{Na}^{+}$and $\mathrm{Cl}^{-}$secretion through salt glands (Marcum 1999). This indicates that the presence of salt glands and $\mathrm{Na}^{+}$exclusion is an important criterion for the primary selection of STGs from the grass species, however the exact mechanism of salinity tolerance in STGs may differ from species to species. Some of the
STG species that are discussed in this review for their salt tolerant genes are recorded in Table 1 with their most probable salt tolerance mechanisms that have been focused in different transgenic experiments.

\section{Mechanisms of salt tolerance in STGs}

The survivability of STGs in saline environment depends greatly up on the art of handling the toxic $\mathrm{Na}^{+}$and replacing it with $\mathrm{K}^{+}$. This is known as the selectivity of $\mathrm{K}^{+}$over $\mathrm{Na}^{+}$. Net selectivity $\left(\mathrm{S}_{\mathrm{K}}\right.$ : Na) is defined as the ratio of $\mathrm{K}^{+}$concentration in the plant tissue to that in the medium divided by the ratio of $\mathrm{Na}^{+}$concentration in the plant to that in the medium, which varies between families of flowering plants (Flowers et al. 1986). According to Flowers and Colmer (2008) $\mathrm{S}_{\mathrm{K}: \mathrm{Na}}$ value in flowering plants ranges between average values of 9 and 60 with an overall mean of 19. In the order Poales the $\mathrm{S}_{\mathrm{K} \text { : Na }}$ values of as high as 60 are found. This makes the grasses a strong subject for studying the ion interactions. Marcum (1999) in his studies on the chloridoid grasses and their salinity tolerance mechanisms pointed out that the tolerance was associated with $\mathrm{Na}^{+}$exclusion through the salt glands present on the epidermis of leaves and with accumulation of the compatible solutes like glycine betaine. The overall mechanisms of tolerance in the salt tolerant grasses are summarised in Figure 1.

Tissue-specific compartmentalisation appears to play an important role in most of the grasses (Lessani and Marschner 1978; Taleisnik 1989; Bhatti et al. 1993), where the toxic ions like $\mathrm{Na}^{+}$and $\mathrm{Cl}^{-}$are redistributed to the mature or senescing leaves and other organs. It is widely accepted that cell turgor is maintained by storage of $\mathrm{Na}^{+}$and $\mathrm{Cl}^{-}$in vacuoles, with the solute potential of the cytosol adjusted by accumulation of $\mathrm{K}^{+}$and organic solutes (Storey 1995). Evidence exists for the presence of $\mathrm{K}^{+} / \mathrm{Na}^{+}$transporter channels across the tonoplast mediated by $\mathrm{Na}^{+} / \mathrm{H}^{+}$antiport activity, resulting in compartmentation of toxic ions in the vacuoles (Jeschke 1984). Ideally in grasses, $\mathrm{Na}^{+}$and $\mathrm{Cl}^{-}$are largely sequestered in

\begin{tabular}{|c|c|}
\hline Grass genera & Mechanism of action \\
\hline Agropyron & Compartmentation of ions, $\mathrm{Na}^{+}$ion exclusion \\
\hline Aeluropus & Compartmentation of ions in to vacuoles \\
\hline Chloris & Enhanced ROS scavenging enzymes \\
\hline Leymus & Osmolyte accumulation \\
\hline Paspalum & Osmolyte accumulation \\
\hline Pennisetum & Compartmentation of ions in to vacuoles \\
\hline Porteresia & Osmolyte accumulation \\
\hline Puccinellia & Enhanced ROS scavenging enzymes, $\mathrm{Na}^{+}$ion exclusion \\
\hline Spartina & Compartmentation of ions in to vacuoles \\
\hline
\end{tabular}




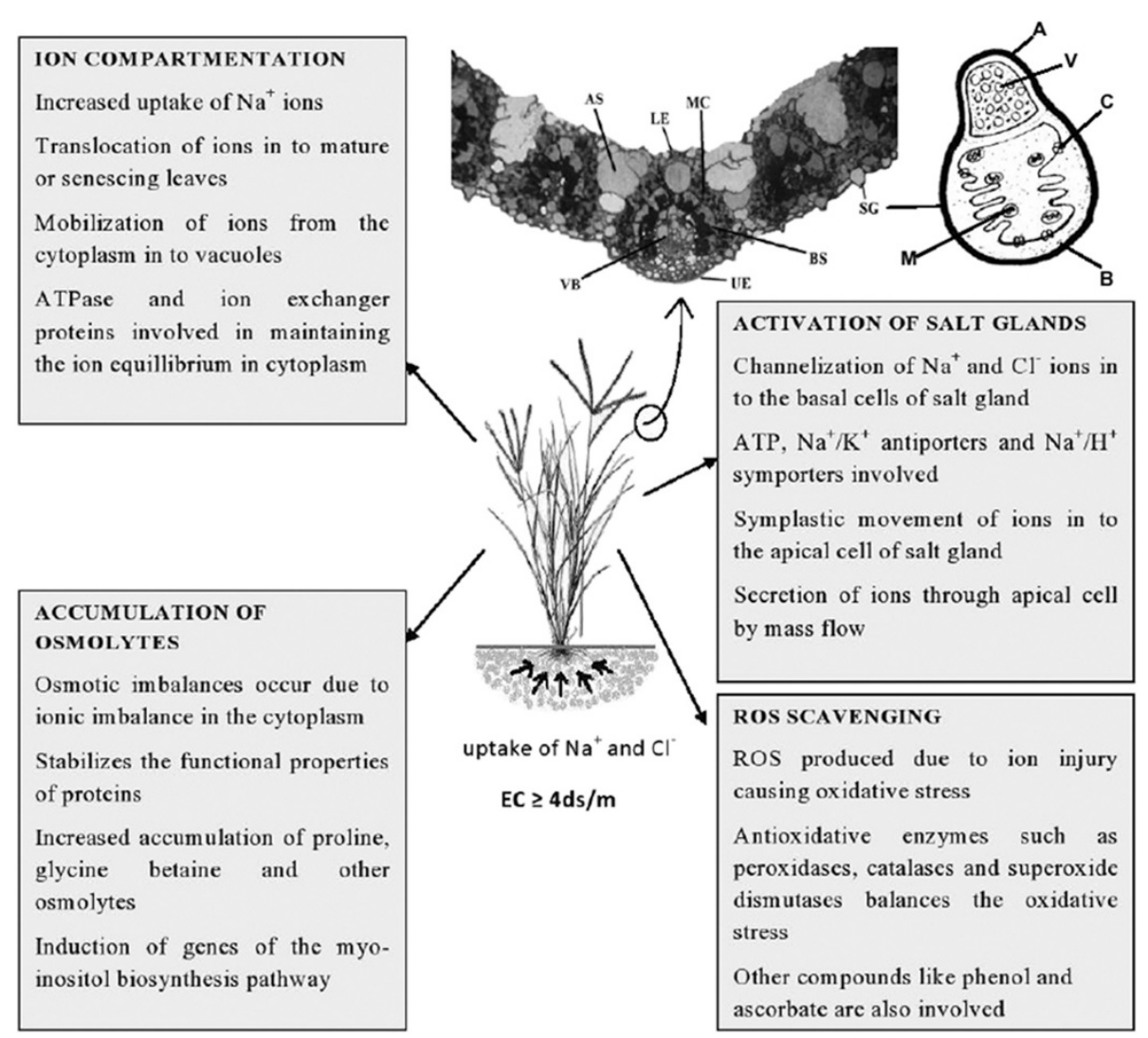

Figure 1 Generalized scheme showing the different aspects of salinity tolerance in salt tolerant grasses (STGs). UE- upper epidermis, LE- lower epidermis, BS- bundle sheath, MC- mesophyll cell, VB- vascular bundle, AS- air space beneath stoma, SG- salt gland, A- apical cell, B- Basal cell, M- mitochondria, C- channel proteins, V-vacuole.

the vacuole of the cell, this sequestering is indicated by the high concentrations of these ions in leaves that are still functioning normally mainly by osmotic adjustments (Marcum 1999).

Salt glands and bladders are the most remarkable organs found in some halophytes which arise from epidermal cells and are modified trichomes (Adams et al. 1998). These specialized organs are meant for secretion of toxic ions from the internal part of plant tissues. The salt glands also appear in the STGs that confers increased salinity tolerance in these plants. Salt glands are usually not found in non halophytes (Ramadan and Flowers 2004). Salt glands appear mostly in the mesophyll tissue of $\mathrm{C} 4$ grasses. The efficiency of $\mathrm{Na}^{+}$exclusion determines the salt tolerance of a particular species (Marcum 2006). Salt glands are generally bicelled in grasses. In Poaceae, bicellular salt glands are found commonly in the tribes: Chlorideae, Sporoboleae and Aeluropodeae (Liphschitz and Waisel 1974). Salt gland excretion in grasses is highly selective for toxic ions like $\mathrm{Na}^{+}$and $\mathrm{Cl}^{-}$(Worku and Chapman 1998), although other ions like $\mathrm{K}^{+}, \mathrm{Ca}^{2+}$ and $\mathrm{Mg}^{2+}$ may also be excreted in small amounts (Marcum and Murdoch 1994). The loading of toxic ions from the adjacent cells in to the salt gland is energy dependent (Naidoo and Naidoo 1999). Flowers et al. (1990) attributed the ability of maintaining a high K: $\mathrm{Na}$ ratio in the leaves to the secretion of toxic ions from the leaves. Most of the grass species, which are glycophyte in their habit, can tolerate high levels of salinity due to the presence of salt glands, and also the possession of salt glands suggests that they had a common halophytic ancestor (Liphschitz and Waisel 1974).

Under salinity stress, the osmotic potential of the cytoplasm and organelles is maintained by the accumulation of organic solutes termed as compatible solutes (Flowers et al. 1977; Wyn Jones and Gorham 1983). At lower concentrations, these solutes works by stabilizing the tertiary structure of proteins and enzymes, and function as osmoprotectants (Rhodes et al. 2002). The most likely candidate in the STGs that plays an important role in maintaining the osmotic balance of the plant cells are glycine betaine and proline (Gorham et al. 1986; Rhodes and Hanson 1993). Marcum (1999) in his experiments with Chloridoid grasses found that glycine betaine concentrations under salinity were positively correlated with salinity tolerance in Chloridoid grasses. Lee et al. (2008) reported synthesis of organic compounds in response to 
salinity stress and their contribution in osmotic adjustments in seashore paspalum grass (Paspalum vaginatum). Organic osmolytes that accumulated most importantly in seashore paspalum under salinity stress were proline, glycine betaine, and trigonelline. Marcum and Murdoch (1994) reported that high accumulation of proline in Cynodon dactylon kept was associated with the maintenance of osmotic balance, thus providing increased salt tolerance. The accumulation of glycine betaine in salt tolerant grasses like Cynodon and Spartina were found to be higher than those reported in wheat, sorghum, and other glycophytic grasses (Grieve and Maas 1984; Wyn Jones and Storey 1981). According to Sengupta et al. (2008), inositols like myo-inositol and pinitol also play an important role in stress tolerance mechanism of salt tolerant grasses like Porteresia coarctata.

Accumulation of reactive oxygen species (ROS) in plant tissues is highly deteriorating as it can cause oxidative damage to proteins, DNA and lipids (Miller et al. 2010). According to Jitesh et al. (2006) most of the halophytes have shown increased efficiency of antioxidative enzymes that helps to negate the harmful effect of ROS. Similarly the STGs also seem to control the $\mathrm{Na}^{+}$induced production of ROS by the increased activity of antioxidative enzymes. Muscolo et al. (2003) studied the activities of different antioxidative enzymes in Pennisetum clandestinum in relation to salinity and found that the grass was tolerant to salt stress up to $100 \mathrm{mM} \mathrm{NaCl}$ due to the up-regulation of ascorbate peroxidase, peroxidase and glutathione reductase enzymes. Seckin et al. (2010) pointed the role of isozymes of antioxidative enzymes such as peroxidase (POX), catalase (CAT), ascorbate peroxidase (APOX) and superoxide dismutase (SOD) in conferring salt tolerance to Hordeum marinum (sea barley grass) plants even at high concentration of $\mathrm{NaCl}(300 \mathrm{mM})$, in comparison to Hordeum vulgare (cultivated barley).

\section{Prospect of STGs in cereal crop improvement Model STGs for cereal crop improvement}

Rice (Oryza sativa) is considered a model plant in monocots because of the relatively small size of its genome, which consists of about $430 \mathrm{Mbp}$ and about 30,000 genes (Komatsu et al. 2003). Apart from rice, Brachypodium distachyon has recently emerged as a model system for grass crop genomic research (Hong et al. 2008). But these model plants are glycophytes and naturally lack the ability to adapt and survive in a saline environment, so they are not ideally suited for the dissection of salt stress related genes. Salt tolerance is a complex trait, and therefore requires intensive studies on the tolerance mechanisms of the salt tolerant species of Poaceae (STGs).

Sengupta and Majumder (2010) proposed Porteresia coarctata, a wild rice, as a potential model for studying salt stress biology in rice. The unique characteristic of this halophytic STG to survive at higher salt concentrations by secretion of excess salts through the leaves has drawn the attention towards it. Due to the availability of complete proteomic information of rice, comparative proteomic study of Porteresia in detail would serve the purpose of identification of newer genes and unique salt tolerance mechanisms in the later (Sengupta and Majumder 2009). Also recently Subudhi and Baisakh (2011) proposed Spartina alterniflora, as a potent halophytic grass model, as it possesses all known mechanisms of salt tolerance. A comparative analysis of DNA sequences of a full-length myoinositol-1-phosphate synthase gene of S. alterniflora (SaMIPS) revealed that it is closer to grass species like maize and rice (Baisakh et al. 2008). Other grasses such as Aeluropus littoralis and Puccinellia tenuiflora also has the potential to become an important source of salt tolerant genes to improve cereal crops (Zouari et al. 2007; Wang et al. 2007). Recent interest on exploring the economically unimportant wild grasses for salt tolerant genes for crop improvement is increasing rapidly and as a result new grasses are being proposed as models for dissection of salt tolerance mechanism and the associated genes. With recent advances, it has become very difficult to concentrate up on a particular species as a model plant. Therefore, it is better to club these potent model plants together, so that the elements of salinity tolerance can be studied together and comparatively. In Figure 2 we have summarized briefly the tools and techniques by which the STG model plants could be employed for cereal crop improvement.

\section{Genes conferring salinity tolerance in STGs}

A significant progress has been made for the identification of genes and their products, which play an important role in the plant system for overcoming the unfavourable situations of abiotic stresses (Cushman and Bohnert 2000). There are several papers published, that documents intensive works on genetic engineering for abiotic stress tolerance and development of transgenics using different candidate genes (Wu et al. 2005; Roy et al. 2011; Reguera et al. 2012). A number of studies for the identification and characterization of genes have also been done in STGs in response to salinity. Subudhi and Baisakh (2011) reported a number of candidate genes encoding transcription factors, ion transporters, osmoprotectants and antioxidants from salt tolerant Spartina alterniflora, upregulated during salt stress. Earlier, analysis of the expression pattern of other genes like cation transport protein $(S a C T P)$, vacuolar ATPase (SaV-ATPase), and plasma membrane protein 3 (SaPMP3) in both leaf and root tissues by reverse transcription PCR (RT-PCR) revealed clear upregulation under salt stress compared to the unstressed control (Baisakh et al. 2008). A number of genes have also been isolated and characterized from Porteresia coarctata that 


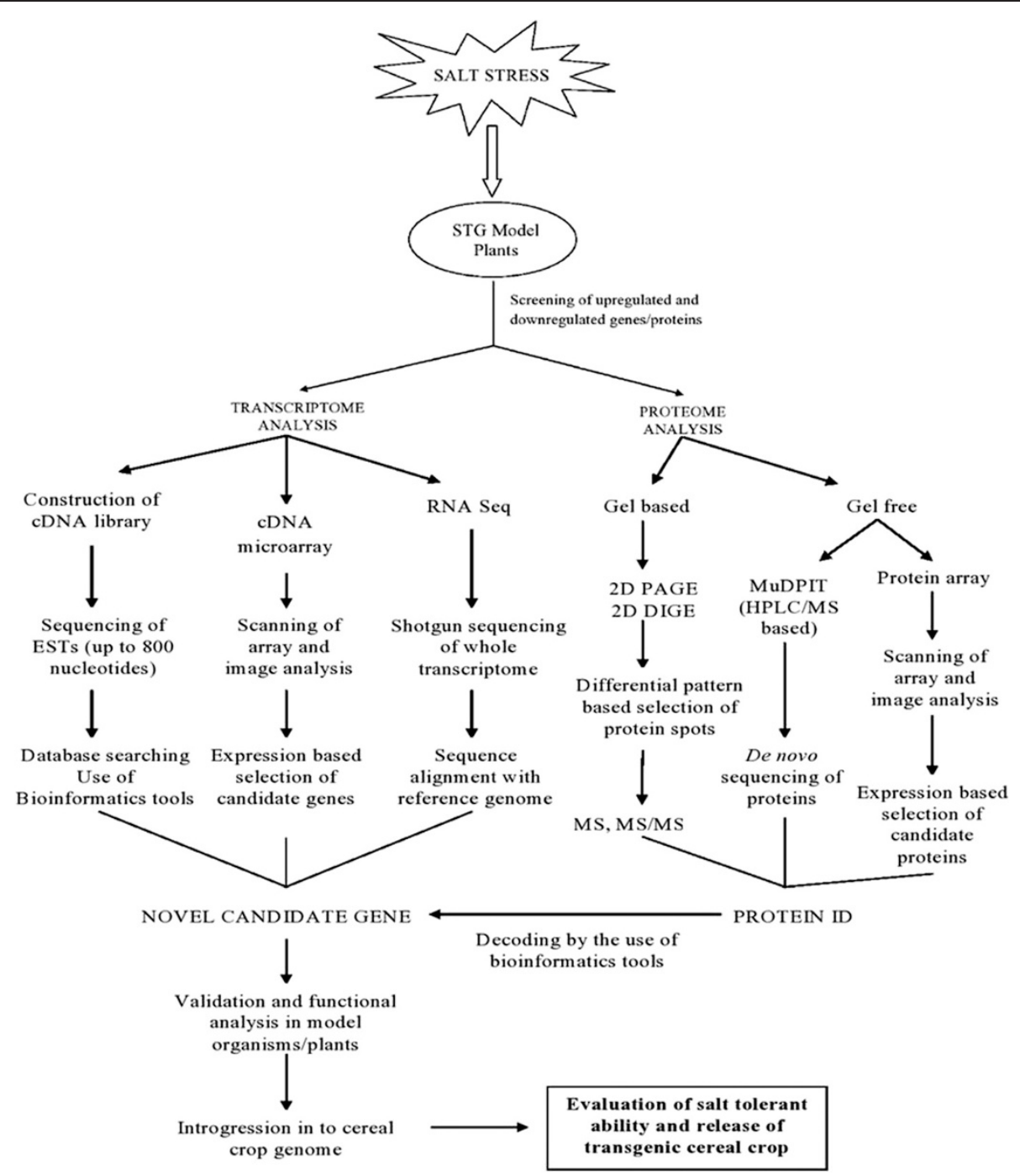

Figure 2 An outline of tools and techniques through which STG model plants can be employed for cereal crop improvement.

are related to the salt tolerance property of the plant, specially the genes operational in inositol metabolic pathway such as myoinositol phosphate synthase (PcMIPS) has been analysed in details (Sengupta and Majumder 2009). A putative UDP galactose epimerase gene and a metallothioneine gene was reported to play an important role in conferring salt tolerance to salt tolerant plants of Paspalum vaginatum (Endo et al. 2005). Wang et al. (2007) identified 162 unique transcripts corresponding to possible saltrelated genes in $P$ tenuiflora. Expression of transcripts encoding an aquaporin, $\mathrm{V}$-ATPase subunit $\mathrm{B}$, and the $\mathrm{Na}^{+} / \mathrm{H}^{+}$ antiporter $N H X$ was characterized from the salt tolerant Festuca rubra ssp. litoralis under salt stress (Diedhiou et al. 2009). Characterization of salt induced ESTs in salt tolerant Aeluropus littoralis revealed that about 20\% of the ESTs bear no resemblance in the protein database and are thus novel (Zouari et al. 2007). The analysis of such ESTs could be important in the development of salt tolerant transgenic cereal crops. A significant number of similar studies on other STGs and also in the glycophytic grasses is required to generated a huge database of genes and ESTs that has salt tolerant attributes.

\section{Transgenic approaches with genes from STGs}

There is an increasing interest to test the novelty of salt tolerant genes through development of transgenic plants. Increased salinity tolerance have been achieved in a range of plant species over expressing $N H X$ gene from the halophytes and non-halophytes, which indicates that these genes are involved in $\mathrm{Na}^{+}$tolerance in plants (Guo et al. 2006). Transgenic approaches to salt tolerance are largely achieved through the overexpression of the genes involved in $\mathrm{Na}^{+}$exclusion from the root or leaves and $\mathrm{Na}^{+}$compartmentalization in the vacuoles (Wang et al. 2003; Bhatnagar-Mathur et al. 2008). In the past decade, vacuolar $\mathrm{Na}^{+} / \mathrm{H}^{+}$antiporters have been the centre of 
attention in transgenic studies for the alleviation of $\mathrm{Na}^{+}$ induced toxicity in plants (Zhang and Blumwald 2001; Vera Estrella et al. 2005; Liu et al. 2008). Several $\mathrm{Na}^{+} / \mathrm{H}^{+}$ antiporter genes have been characterized from STGs and have been showed to impart salt tolerance in transgenic experiments (Qiao et al. 2007; Zhang et al. 2008). Also other genes such as myo-inositol phosphate synthase, ascorbate peroxidase and other transcription factors different STGs and are shown to impart salinity tolerance in transgenic experiments (Majee et al. 2004; Guan et al.

Table 2 Genes from STGs and non-STGs imparting enhanced salinity tolerance in transgenic studies

\begin{tabular}{|c|c|c|c|c|c|}
\hline Source & Gene & Description & $\begin{array}{l}\text { Target } \\
\text { organism }\end{array}$ & Inference & Reference \\
\hline \multirow{2}{*}{$\begin{array}{l}\text { Agropyron } \\
\text { elongatum* }\end{array}$} & \multirow[t]{2}{*}{ AeNHX1 } & \multirow[t]{2}{*}{ Vacuolar $\mathrm{Na}^{+} / \mathrm{H}^{+}$antiporter } & Arabidopsis sp. & \multirow[t]{2}{*}{ Root specific compartmentation of $\mathrm{Na}^{+}$ions } & \multirow[t]{2}{*}{ Qiao et al. 2007} \\
\hline & & & Festuca sp. & & \\
\hline \multirow[t]{2}{*}{$\begin{array}{l}\text { Aeluropus } \\
\text { littoralis* }\end{array}$} & AlNHX1 & Vacuolar $\mathrm{Na}^{+} / \mathrm{K}^{+}$antiporters & $\begin{array}{l}\text { Nicotiana } \\
\text { tabacum }\end{array}$ & $\begin{array}{l}\text { Compartmentalize more } \mathrm{Na}^{+} \text {in roots and } \\
\text { keep a relatively high } \mathrm{K}^{+} / \mathrm{Na}^{+} \text {ratio in leaves }\end{array}$ & Zhang et al. 2008 \\
\hline & AISAP & $\begin{array}{l}\text { Two conserved zinc-finger } \\
\text { domains A20 and AN1 }\end{array}$ & $\begin{array}{l}\text { Nicotiana } \\
\text { tabacum }\end{array}$ & $\begin{array}{l}\text { Transgenic plants able to set seed at up } \\
\text { to } 350 \mathrm{mM} \mathrm{NaCl}\end{array}$ & Saad et al. 2010 \\
\hline $\begin{array}{l}\text { Chloris } \\
\text { virgata* }\end{array}$ & ChIMT1 & Metallothioneine & Saccharomyces & Increases tolerance to salinity and ROS & $\begin{array}{l}\text { Nishiuchi et al. } \\
2007\end{array}$ \\
\hline \multirow[t]{2}{*}{$\begin{array}{l}\text { Hordeum } \\
\text { vulgare }\end{array}$} & HVA1 & $\begin{array}{l}\text { Encodes a group of } 3 \text { late } \\
\text { embryogenesis abundant } \\
\text { (LEA) proteins }\end{array}$ & Morus alba & $\begin{array}{l}\text { Enhanced salinity tolerance by increased } \\
\text { accumulation of proline }\end{array}$ & Lal et al. 2008 \\
\hline & $H V N H X 2$ & Vacuolar $\mathrm{Na}^{+} / \mathrm{H}^{+}$antiporter & $\begin{array}{l}\text { Arabidopsis } \\
\text { thaliana }\end{array}$ & Able to grow at $200 \mathrm{mM} \mathrm{NaCl}$ & Bayat et al. 2011 \\
\hline \multirow[t]{2}{*}{$\begin{array}{l}\text { Leymus } \\
\text { chinensis* }\end{array}$} & LCDREB3a & $\begin{array}{l}\text { Dehydration-responsive } \\
\text { element-binding transcription } \\
\text { factor }\end{array}$ & $\begin{array}{l}\text { Arabidopsis } \\
\text { thaliana }\end{array}$ & $\begin{array}{l}\text { Improved abiotic stress tolerance including } \\
\text { salinity with no retardation in growth }\end{array}$ & Xianjun et al. 2011 \\
\hline & LCMYB-1 & MYB related transcription factor & $\begin{array}{l}\text { Arabidopsis } \\
\text { thaliana }\end{array}$ & $\begin{array}{l}\text { Enhanced salinity tolerance due to increased } \\
\text { accumulation of proline and soluble sugars }\end{array}$ & Cheng et al. 2013 \\
\hline $\begin{array}{l}\text { Oryza } \\
\text { rufipogon }\end{array}$ & OrbHLHOO1 & $\begin{array}{l}\text { Basic helix-loop-helix (bHLH) } \\
\text { protein gene }\end{array}$ & $\begin{array}{l}\text { Arabidopsis } \\
\text { thaliana }\end{array}$ & Improved salinity tolerance in transgenic plants & Li et al. 2010 \\
\hline Oryza sativa & OsNHX1 & $\mathrm{Na}^{+} / \mathrm{H}^{+}$antiporter & Populus sp. & $\begin{array}{l}\text { transgenic plants grew normally in the presence } \\
\text { of } 200 \mathrm{mM} / \mathrm{l} \mathrm{NaCl}\end{array}$ & Wang et al. 2005 \\
\hline \multirow[t]{2}{*}{$\begin{array}{l}\text { Paspalum } \\
\text { vaginatum* }\end{array}$} & PVUGE1 & $\begin{array}{l}\text { Putative UDP-galactose } \\
\text { epimerase }\end{array}$ & Oryza sativa & Enhanced salinity tolerance & Endo et al. 2005 \\
\hline & PVMET1 & Metallothioneine & Oryza sativa & Enhanced salinity tolerance & Endo et al. 2005 \\
\hline $\begin{array}{l}\text { Pennisetum } \\
\text { glaucum* }\end{array}$ & PgNHX1 & Vacuolar $\mathrm{Na}^{+} / \mathrm{H}^{+}$antiporter & Oryza sativa & $\begin{array}{l}\text { Induced more extensive root system and } \\
\text { completion of life cycle of rice at } 150 \mathrm{mM} \mathrm{NaCl}\end{array}$ & Verma et al. 2007 \\
\hline \multirow[t]{2}{*}{$\begin{array}{l}\text { Porteresia } \\
\text { coarctata* }\end{array}$} & PCINO1 & $\begin{array}{l}\text { Synthesis of L- myoinositol-1 } \\
\text { phosphate synthase }\end{array}$ & $\begin{array}{l}\text { Nicotiana } \\
\text { tabacum }\end{array}$ & $\begin{array}{l}\text { Tobacco plants showed growth in 200-300 mM } \\
\mathrm{NaCl}\end{array}$ & Majee et al. 2004 \\
\hline & PCSrp & $\begin{array}{l}\text { Root-specific cDNA encoding } \\
\text { serine-rich-protein }\end{array}$ & $\begin{array}{l}\text { Eleusine } \\
\text { coracana }\end{array}$ & $\begin{array}{l}\text { Transgenic plants able to grow and set seed } \\
\text { at } 250 \mathrm{mM} \mathrm{NaCl}\end{array}$ & $\begin{array}{l}\text { Mahalakshmi } \\
\text { et al. } 2006\end{array}$ \\
\hline \multirow[t]{2}{*}{$\begin{array}{l}\text { Puccinellia } \\
\text { tenuiflora* }\end{array}$} & PutAPx & $\begin{array}{l}\text { Ascorbate peroxidase } \\
\text { coding gene }\end{array}$ & Saccharomyces & $\begin{array}{l}\text { Imparted higher resistance to salinity induced } \\
\text { oxidative stress }\end{array}$ & Guan et al. 2011 \\
\hline & $\begin{array}{l}\text { AKT-1-type- } K^{+} \\
\text {channel }\end{array}$ & $\begin{array}{l}\text { Plasma membrane } \mathrm{K}^{+} \text {channel } \\
\text { protein }\end{array}$ & $\begin{array}{l}\text { Arabidopsis } \\
\text { thaliana }\end{array}$ & $\begin{array}{l}\text { Increased accumulation of } \mathrm{K}^{+} \text {ion as compared } \\
\text { to } \mathrm{Na}^{+}\end{array}$ & Ardie et al. 2010 \\
\hline \multirow{2}{*}{$\begin{array}{l}\text { Spartina } \\
\text { alterniflora* }\end{array}$} & SaVHAC1 & Vacuolar $\mathrm{H}^{+}$ATPase subunit C1 & Oryza sativa & Enhanced salinity tolerance in rice & Baisakh et al. 2012 \\
\hline & Sasceg & $\begin{array}{l}\text { Small ubiquitin related modifier } \\
\text { (SUMO) conjugating enzyme }\end{array}$ & $\begin{array}{l}\text { Arabidopsis } \\
\text { thaliana }\end{array}$ & $\begin{array}{l}\text { Enhanced salinity and drought tolerance } \\
\text { by inducing stress responsive genes }\end{array}$ & $\begin{array}{l}\text { Karan and } \\
\text { Subudhi } 2012\end{array}$ \\
\hline \multirow[t]{3}{*}{$\begin{array}{l}\text { Triticum } \\
\text { aestivum }\end{array}$} & TaNIP & $\begin{array}{l}\text { Nodulin 26-like intrinsic protein } \\
\text { (novel aquaporin gene) }\end{array}$ & $\begin{array}{l}\text { Arabidopsis } \\
\text { thaliana }\end{array}$ & $\begin{array}{l}\text { Enhanced salt tolerance by accumulation of } \\
\text { higher } \mathrm{K}^{+} \text {and proline }\end{array}$ & Gao et al. 2010 \\
\hline & TaST & Unknown salt-induced gene & $\begin{array}{l}\text { Arabidopsis } \\
\text { thaliana }\end{array}$ & $\begin{array}{l}\text { Enhanced salt tolerance by accumulating } \\
\text { more } \mathrm{Ca}^{2+} \text {, soluble sugar, and proline and } \\
\text { less } \mathrm{Na}^{+}\end{array}$ & Huang et al. 2012 \\
\hline & TaNHX2 & Vacuolar $\mathrm{Na}^{+} / \mathrm{H}^{+}$antiporter & Medicago sativa & Enhanced salt tolerance & Zhang et al. 2012 \\
\hline Zea mays & ZmPMP3-1 & Plasma membrane protein & $\begin{array}{l}\text { Arabidopsis } \\
\text { thaliana }\end{array}$ & $\begin{array}{l}\text { Enhanced salinity tolerance by regulation of } \\
\text { ion homeostasis and ROS scavenging }\end{array}$ & Fu et al. 2012 \\
\hline
\end{tabular}


2011; Cheng et al. 2013). Some of the salt tolerant genes derived from STGs that conferred salinity tolerance in different transgenic experiments are listed in Table 2. Some of the salt tolerant genes from non STGs (exclusively grasses) are also mentioned.

\section{Conclusion}

STGs offer a promising system for the analysis of the mechanisms associated with salinity stress tolerance. The inherent potentiality of these grasses to counteract the negative impacts of salinity is very encouraging for the dissection of more and more novel salt tolerant genes. Also due to their close affinity to the cereal crops, the success of transgenic experiments with the genes from STGs in cereal crops is expected to be very pronounced. Salt tolerance is a complex physiological trait and it has been very difficult to translate the outcome of laboratory experiments in the field, which urges the need for increasing the evaluation of transgenic plants under field conditions (Jewell et al. 2010). Moreover, the very fact that salt tolerance in grasses is an evolutionary labile trait and difficult to transfer in the cereal crops (Bennett et al. 2013), makes it a difficult proposition; still the STGs are emerging as an important plant system that will lead to improved understanding of the gene networks and molecular physiology of cereal crops under salinity stresses. Therefore, further exploration is needed to test the contribution of single or multiple salt stress related genes or regulatory factors from the STGs including Spartina alterniflora, Porteresia coarctata, Puccinellia tenuiflora, Aeluropus littoralis, Agropyron elongatum and other potent STGs for possible utilization in cereal crop improvement.

\section{Abbreviations}

STGs: Salt tolerant grasses; ROS: Reactive oxygen species; POX: Peroxidase; CAT: Catalase; APOX: Ascorbate peroxidase; SOD: Superoxide dismutase; MIPS: Myoinositol phosphate synthase; CTP: Cation transport protein; PMP: Plasma membrane protein; PCR: Polymerase chain reaction; ESTs: Expressed sequence tags.

\section{Competing interests}

Authors declare that there is no competing interest between the authors.

\section{Authors' contributions}

SR was involved in collection of data and main write-up. UC was involved in checking and critical evaluation of the review. Both authors read and approved the final manuscript.

Received: 17 January 2014 Accepted: 10 March 2014 Published: 14 March 2014

\section{References}

Adams P, Nelson DE, Yamada S, Chmara W, Jensen RG, Bohnert HJ, Griffiths H (1998) Growth and development of Mesembryanthemum crystallinum (Aizoaceae). New Phytol 138:171-190

Ardie SW, Liu S, Takano T (2010) Expression of the AKT1-type K(+) channel gene from Puccinellia tenuiflora, PutAKT1, enhances salt tolerance in Arabidopsis. Plant Cell Rep 29(8):865-874

Baisakh N, Rao MVR, Rajasekaran K, Subudhi P, Janda J, Galbraith D, Vanier C, Pereira A (2012) Enhanced salt stress tolerance of rice plants expressing a vacuolar $\mathrm{H}^{+}$-ATPase subunit $\mathrm{C} 1$ (SaVHAC1) gene from the halophyte grass Spartina alterniflora Loisel. Plant Biotech J 10(4):453-464

Baisakh N, Subudhi PK, Bhardwaj P (2008) Primary responses to salt stress in a halophyte, smooth cordgrass (Spartina alterniflora Loisel.). Funct Integr Genomic 8:287-300

Barhoumi Z, Djebali W, Abdelly C, Chaibi W, Smaoui A (2008) Ultrastructure of Aeluropus littoralis leaf salt glands under $\mathrm{NaCl}$ stress. Protoplasma 233:195-202

Bayat F, Shiran B, Belyaev DV (2011) Overexpression of HvNHX2, a vacuolar $\mathrm{Na}^{+} / \mathrm{H}^{+}$antiporter gene from barley, improves salt tolerance in Arabidopsis thaliana. Aust J Crop Sci 5(4):428-432

Bennett TH, Flowers TJ, Bromham L (2013) Repeated evolution of salt-tolerance in grasses. Biol Lett 9(2):20130029

Bhatnagar-Mathur P, Vadez V, Sharma KK (2008) Transgenic approaches for abiotic stress tolerance in plants: retrospect and prospects. Plant Cell Rep 27:411-424

Bhatti AS, Steinert S, Sarwar G, Hilpert A, Jeschke WD (1993) Ion distribution in relation to leaf age in Leptochloa fusca (L.). Kunth. (kallar grass). I. K., Na, Ca and Mg. New Phytol 123:539-545

Chaves M, Davies B (2010) Drought effects and water use efficiency: improving crop production in dry environments. Funct Plant Biol 37:3-6

Cushman JC, Bohnert HJ (2000) Genomic approaches to plant stress tolerance. Curr Opin Plant Biol 3:117-124

Cheng L, Li X, Huang X, Ma T, Liang Y, Ma X, Peng X, Jia J, Chen S, Chen Y, Deng B, Liu G (2013) Overexpression of sheep grass R1-MYB transcription factor LCMYB1 confers salt tolerance in transgenic Arabidopsis. Plant Physiol Bioch 70:252-260

Diedhiou CJ, Popova OV, Golldack D (2009) Transcript profiling of the salt-tolerant Festuca rubra ssp. Litoralis reveals a regulatory network controlling salt acclimatization. J Plant Physiol 166(7):697-711

Endo N, Yoshida K, Akiyoshi M, Yoshida Y, Hayashi N (2005) Putative UDP-galactose epimerase and metallothioneine of Paspalum vaginatum enhanced the salt tolerance of rice, Oryza sativa L. from transplanting to harvest stages. Breeding Sci 55:163-173

Flowers TJ, Colmer TD (2008) Salinity tolerance in halophytes. New Phytol 179:945-963

Flowers TJ, Flowers SA, Hajibagheri MA, Yeo AR (1990) Salt tolerance in halophytic wild rice, Porteresia coarctata Tateoka. New Phytol 114:675-684

Flowers TJ, Galal HK, Bromham L (2010) Evolution of halophytes: multiple origins of salt tolerance in land plants. Funct Plant Biol 37:604-612

Flowers TJ, Hajibagheri MA, Clipson NJW (1986) Halophytes. Quart Rev Biol 61:313-337

Flowers TJ, Troke PF, Yeo AR (1977) The mechanism of salt tolerance in halophytes. Annu Rev Plant Physiol 28:89-121

Fu J, Zhang DF, Liu YH, Ying S, Shi YS (2012) Isolation and characterization of maize PMP3 genes involved in salt stress tolerance. PLoS One 7(2):e31101

Gao Z, He X, Zhao B, Zhou C, Liang Y, Ge R, Shen Y, Huang Z (2010) Overexpressing a putative aquaporin gene from wheat, TaNIP, enhances salt tolerance in transgenic Arabidopsis. Plant Cell Physiol 51(5):767-775

Gorham J, Budrewicz E, McDonnell E, Wyn Jones RG (1986) Salt tolerance in the Triticeae: salinity-induced changes in leaf solute composition of some perennial Triticeae. J Exp Bot 37:1114-1128

Gorham J, Wyn Jones RG, McDonnell E (1985) Some mechanisms of salt tolerance in crop plants. Plant Soil 89:15-40

Grieve CM, Maas EV (1984) Betaine accumulation in salt-stressed sorghum. Physiol Plantarum 61:167-171

Guan Q, Li L, Tetsuo T, Liu S (2011) Cloning of an ascorbate peroxidase gene from Puccinellia tenuiflora and its expression analysis. Genom App Biol 28(4):631-639

Guo SL, Yin HB, Zhang X, Zhao FY, Li PH, Chen SH, Zhao YX, Zhang H (2006) Molecular cloning and characterization of a vacuolar $\mathrm{H}^{+}$-pyrophosphatase gene, SSVP, from the halophyte Suaeda salsa and its overexpression increases salt and drought tolerance of Arabidopsis. Plant Mol Biol 60:41-50

Hong SY, Seo PJ, Yang MS, Xiang F, Park CM (2008) Exploring valid reference genes for gene expression studies in Brachypodium distachyon by real-time PCR. BMC Plant Biol 8:112

Huang X, Wang G, Shen Y, Huang Z (2012) The wheat gene TaST can increase the salt tolerance of transgenic Arabidopsis. Plant Cell Rep 31(2):339-347

Jeschke WD (1984) $\mathrm{K}^{+}-\mathrm{Na}^{+}$exchange at cellular membranes, intracellular compartmentation of cations, and salt tolerance. In: Staples RC, Toenniessen GH (eds) Salinity Tolerance in Plants. Wiley, New York, pp 37-66 
Jewell MC, Campbell BC, Godwin ID (2010) Transgenic plants for abiotic stress resistance. In: Kole C, Michler CH, Abbott AG, Hall TC (eds) Transgenic Crop Plants. Springer, Heidelberg, pp 67-132

Jitesh MN, Prasanth SR, Sivaprakash KR, Parida AK (2006) Antioxidant response mechanism in halophytes: their role in stress defence. J Gen 85(3):237-254

Karan R, Subudhi PK (2012) A stress inducible SUMO conjugating enzyme gene (SaSce9) from a grass halophyte Spartina alterniflora enhances salinity and drought stress tolerance in Arabidopsis. BMC Plant Biol 12:187

Komatsu S, Konishi H, Shen S, Yang G (2003) Rice proteomics: a step toward functional analysis of the rice genome. Mol Cell Proteomics 2:2-10

Lal S, Gulyani V, Khurana P (2008) Overexpression of HVA1 gene from barley generates tolerance to salinity and water stress in transgenic mulberry (Morus indica). Transgenic Res 17(4):651-663

Lauchli A, Grattan SR (2007) Plant growth and development under salinity stress. In: Jenks MA, Hasegawa PM, Jain SM (eds) Advances in Molecular Breeding Toward Drought and Salt Tolerant Crops. Springer, Heidelberg, pp 1-32

Lee GJ, Carrow RN, Duncan RR, Eiteman MA, Rieger MW (2008) Synthesis of organic osmolytes and salt tolerance mechanisms in Paspalum vaginatum. Environ Exp Bot 63:19-27

Lessani H, Marschner H (1978) Relation between salt tolerance and long-distance transport of sodium and chloride in various crop species. Aust J Plant Physiol 5:27-37

Li F, Guo S, Zhao Y, Chen D, Chong K, Xu Y (2010) Overexpression of a homopeptide repeat-containing bHLH protein gene (OrbHLH001) from Dongxiang Wild Rice confers freezing and salt tolerance in transgenic Arabidopsis. Plant Cell Rep 29:977-986

Liphschitz N, Waisel Y (1974) Existence of salt glands in various genera of Gramineae. New Phytol 73:507-513

Liu H, Wang Q, Yu M, Zhang Y, Wu Y, Zhang H (2008) Transgenic salt-tolerant sugar beet (Beta vulgaris L.) constitutively overexpressing an Arabidopsis thaliana vacuolar $\mathrm{Na}^{+} / \mathrm{H}^{+}$antiporter gene, AtNHX3, accumulates more soluble sugar but less salt in storage root. Plant Cell Environ 31:1325-1334

Mahalakshmi S, Christopher GSB, Reddy TP, Rao KV, Reddy VD (2006) Isolation of a cDNA clone (PcSrp) encoding serine-rich-protein from Porteresia coarctata T. and its expression in yeast and finger millet (Eleusine coracana L.) affording salt tolerance. Planta 224(2):347-359

Majee M, Maitra S, Dastidar KG, Pattanaik S, Chatterjee A, Hait NC, Das KP, Majumder AL (2004) A novel salt tolerant L-myo-Inositol-1-phosphate synthase from Porteresia coarctata (Roxb.) Tateoka, a halophytic wild rice: molecular cloning, bacterial overexpression, characterization, and functional introgression into tobacco-conferring salt tolerance phenotype. J Biol Chem 279:28539-28552

Marcum KB (1999) Salinity tolerance mechanism of grasses in the sub-family Chloridoideae. Crop Sci 39(4):1153-1160

Marcum KB (2006) Saline tolerance physiology in grasses. In: Khan MA, Weber DJ (eds) Ecophysiology of High Salinity Tolerant Plants. Springer, Heidelberg, pp 157-172

Marcum KB, Murdoch CL (1994) Salinity tolerance mechanisms of six C4 turfgrasses. J Am Soc Hort Sci 119:779-784

Miller G, Suzuki N, Ciftci-Yilmaz S, Mittler R (2010) Reactive oxygen species homeostasis and signaling during drought and salinity stresses. Plant Cell Environ 33(4):453-467

Munns R, Tester M (2008) Mechanisms of salinity tolerance. Annu Rev Plant Biol 59:651-681

Muscolo A, Sidari M, Panuccio MR (2003) Tolerance of kikuyu grass to long term salt stress is associated with induction of antioxidant defences. Plant Growth Regul 41(1):57-62

Naidoo Y, Naidoo G (1999) Cytochemical localization of adenosine triphosphatase activity in salt glands of Sporobolus virginicus (L.) Kunth. S Afr J Bot 65:370-373

Nellemann C, Devette MM, Manders T (2009) The Environmental Food Crisis: The Environment's role in averting future food crisis: A UNEP rapid response assessment. United Nations Environment Programme of the United Nations, Nairobi

Nishiuchi S, Liu S, Takano T (2007) Isolation and characterization of a metallothionein-1 protein in Chloris virgata Swartz that enhances stress tolerance to oxidative, salinity and carbonate stress in Saccharomyces cerevisiae. Biotechnol Lett 29(8):1301-1305

Oross JW, Thomson WW (1982) The ultrastructure of salt glands of Cynodon and Distichlis (Poaceae). Am J Bot 69(6):939-949

Prakash A, Stigler M (2012) FAO Statistical Yearbook. Food and Agriculture Organization of the United Nations, Rome
Qiao WH, Zhao XY, Li W, Luo Y, Zhang XS (2007) Overexpression of AeNHX1, a root-specific vacuolar $\mathrm{Na}^{+} / \mathrm{H}^{+}$antiporter from Agropyron elongatum, confers salt tolerance to Arabidopsis and Festuca plants. Plant Cell Rep 26:1663-1672

Ramadan T, Flowers JJ (2004) Effects of salinity and benzyl adenine on development and function of microhairs of Zea mays L. Planta 219:639-648

Reguera M, Peleg Z, Blumwald E (2012) Targeting metabolic pathways for genetic engineering abiotic stress-tolerance in crops. Biochim Biophys Acta 1819(2):186-194

Rhodes D, Hanson AD (1993) Quarternary ammonium and tertiary sulfonium compounds in higher plants. Annu Rev Plant Physiol Plant Mol Biol 44:357-384

Rhodes D, Nadolska-Orczyk A, Rich PJ (2002) Salinity, osmolytes and compatible solutes. In: Lauchli U, Luttge U (eds) Salinity: Environment - Plants - Molecules. Kluwer, Dordrecht, Netherlands, pp 181-204

Roy B, Noren SK, Mondal AB, Basu AK (2011) Genetic engineering for abiotic stress tolerance in agricultural crops. Biotechnol 10:1-22

Saad RB, Zouari N, Ramdhan WB, Azaza J, Meynard D, Guiderdoni E, Hassairi A (2010) Improved drought and salt stress tolerance in transgenic tobacco overexpressing a novel A20/AN1 zinc-finger "AISAP" gene isolated from the halophyte grass Aeluropus littoralis. Plant Mol Biol 72:171-190

Seckin B, Turkan I, Sekmen AH, Ozfidan C (2010) The role of antioxidant defense systems at differential salt tolerance of Hordeum marinum Huds. (sea barley grass) and Hordeum vulgare L. (cultivated barley). Environ Exp Bot 69(1):76-85

Sengupta S, Majumder AL (2009) Insight into the salt tolerance factors of a wild halophytic rice, Porteresia coarctata: a physiological and proteomic approach. Planta 229:911-929

Sengupta S, Majumder AL (2010) Porteresia coarctata (Roxb.) Tateoka, a wild rice: A potential model for studying salt-stress biology in rice. Plant Cell Environ 33:526-542

Sengupta S, Patra B, Ray S, Majumder AL (2008) Inositol methyl transferase from a halophytic wild rice, Porteresia coarctata Roxb. (Tateoka): regulation of pinitol synthesis under abiotic stress. Plant Cell Environ 31:1442-1459

Storey R (1995) Salt tolerance, ion relations and the effect of root medium on the response of citrus to salinity. Aust J Plant Physiol 22:101-114

Subudhi PK, Baisakh N (2011) Spartina alterniflora Loisel., a halophyte grass model to dissect salt stress tolerance. In Vitro Cell Dev Biol Plant 47:441-457

Taleisnik EL (1989) Sodium accumulation in Pappophorum I. uptake, transport and recirculation. Ann Botany 63:221-228

Teakle NL, Bazihizina N, Shabala SN, Colmer TD, Barrett-Lennard EG, Rodrigo-Moreno A, Lauchli AE (2013) Differential tolerance to combined salinity and $\mathrm{O}_{2}$ deficiency in the halophytic grasses Puccinellia ciliata and Thinopyrum ponticum: The importance of $\mathrm{K}^{+}$retention in roots. Environ Exp Bot 87:69-78

Tester M, Bacic A (2005) Abiotic stress tolerance in grasses - From model plants to crop plants. Plant Physiol 137:791-793

Verma D, Singla-Pareek SL, Rajagopal D, Reddy MK, Sopory SK (2007) Functional validation of a novel isoform of $\mathrm{Na}^{+} / \mathrm{H}^{+}$antiporter from Pennisetum glaucum for enhancing salinity tolerance in rice. J Biosci 32:621-628

Wang S, Chen Q, Wang W, Wang X, Lu M (2005) Salt tolerance conferred by over-expression ofOsNHX1 gene in Poplar 84 K. Chin Sci Bull 50(3):225-229

Wang W, Vinocur B, Altman A (2003) Plant responses to drought, salinity and extreme temperatures: towards genetic engineering for stress tolerance. Planta 218:1-14

Wang Y, Chu Y, Liu G, Wang MH, Jiang J, Hou Y, Qu G, Yang C (2007) Identification of expressed sequence tags in an alkali grass (Puccinellia tenuiflora) cDNA library. J Plant Physiol 164(1):78-89

Watson L, Dallwitz MJ (1992) The grass genera of the world. CAB International publishers, UK, pp 1038

Worku W, Chapman GP (1998) The salt secretion physiology of a Chloridoid grass, Cynodon dactylon (L.) Pers., and its implications. Sinet 21:1-16

Wu L, Fan Z, Guo L, Li Y, Chen ZL, Qu LJ (2005) Over-expression of the bacterial nhaA gene in rice enhances salt and drought tolerance. Plant Sci 168:297-302

Wyn Jones RG, Gorham J (1983) Osmoregulation. In: Lange OL, Nobel PS, Osmond CB, Ziegler H (eds) Physiological Plant Ecology III. Responses to the Chemical and Biological Environment. Springer-Verlag, Berlin, pp 35-58

Wyn Jones RG, Storey R (1981) Betaines. In: Paleg LG, Aspinall D (eds) Physiology and Biochemistry of Drought Resistance in Plants. Academic Press, Australia, pp 171-204

Vera Estrella R, Barkla BJ, Garcia-Ramirez L, Pantoja O (2005) Salt stress in Thellungiella halophila activates $\mathrm{Na}^{+}$transport mechanisms required for salinity tolerance. Plant Physiol 139:1507-1517 
Xianjun P, Xingyong M, Weihong F, Man S, Liqin C, Alam I, Lee BH, Dongmei Q, Shihua S, Gongshe L (2011) Improved drought and salt tolerance of Arabidopsis thaliana by transgenic expression of a novel DREB gene from Leymus chinensis. Plant Cell Rep 30(8):1493-1502

Zhang HX, Blumwald E (2001) Transgenic salt-tolerant tomato plants accumulate salt in foliage but not in fruit. Nat Biotechnol 19:765-768

Zhang GH, Su Q, An LJ, Wu S (2008) Characterization and expression of a vacuolar $\mathrm{Na}^{+} / \mathrm{H}^{+}$antiporter gene from the monocot halophyte Aeluropus littoralis. Plant Physiol Biochem 46(2):117-126

Zhang YM, Liu ZH, Wen ZY, Zhang HM, Yang F, Guo XL (2012) The vacuolar $\mathrm{Na}^{+}-\mathrm{H}^{+}$antiport gene TaNHX2 confers salt tolerance on transgenic alfalfa (Medicago sativa). Func Plant Biol 39(8):708-716

Zouari N, Saad RB, Legavre T, Azaza J, Sabau X, Jaoua M, Masmoudi K, Hassairi A (2007) Identification and sequencing of ESTs from the halophyte grass Aeluropus littoralis. Gene 404:61-69

doi:10.1186/1999-3110-55-31

Cite this article as: Roy and Chakraborty: Salt tolerance mechanisms in Salt Tolerant Grasses (STGs) and their prospects in cereal crop improvement. Botanical Studies 2014 55:31.

\section{Submit your manuscript to a SpringerOpen ${ }^{\circ}$ journal and benefit from:}

- Convenient online submission

- Rigorous peer review

- Immediate publication on acceptance

- Open access: articles freely available online

- High visibility within the field

- Retaining the copyright to your article 